\title{
Historein
}

Vol 15, No 1 (2015)

Revisiting Democratic Transitions in Times of Crisis

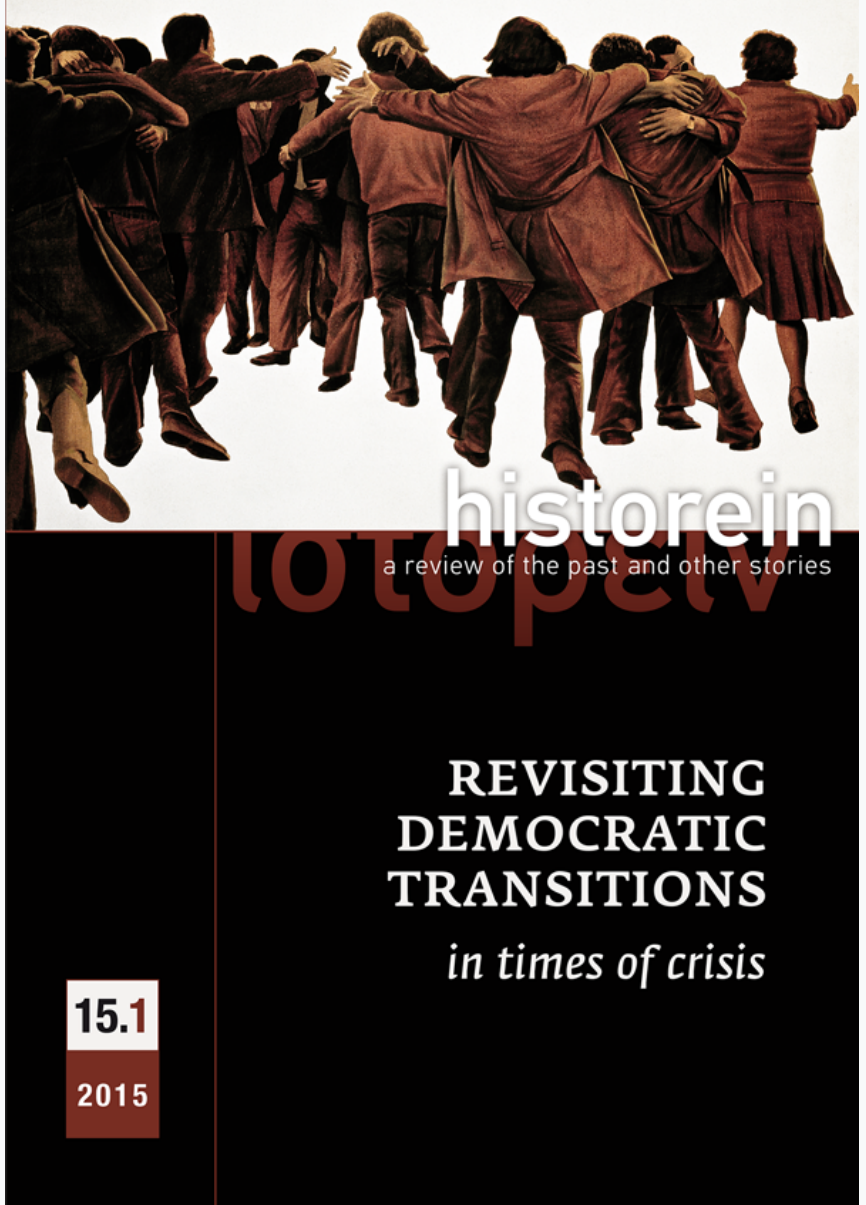

Review of Alexis Rappas' Cyprus in the 1930s: British Colonial Rule and the Roots of the Cyprus Conflict

Eleni Braat

doi: $10.12681 /$ historein.304

Copyright $@ 2015$, Eleni Braat

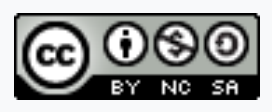

This work is licensed under a Creative Commons Attribution-NonCommercialShareAlike 4.0.

To cite this article:

Braat, E. (2022). Review of Alexis Rappas' Cyprus in the 1930s: British Colonial Rule and the Roots of the Cyprus Conflict. Historein, 15(1), 167-170. https://doi.org/10.12681/historein.304 
and-arts/21599798-first-world-war-wasdefining-event-20th-century-thousandsbooks-have.

See, for example, the review of the book by Miloš Vojinović in Balcanica 44 (2013): 422432, where a bibliography is provided. See also Boris Begović, "In Search of Lost Time: A View of Contemporary Historiography on the Origins of the First World War," Balcanica 45 (2014): 463-466.

See Nikos Bakounakis, "Yпvoßátєৎ," To Vima, 8 Feb. 2015, accessed 21 Jul. 2015, www. tovima.gr/opinions/article/?aid=674939.

\section{Alexis Rappas \\ Cyprus in the 1930s: British \\ Colonial Rule and the Roots of the Cyprus Conflict}

\section{London: IB Tauris, 2014. 320 pp.}

\section{Eleni Braat}

Utrecht University

The 1931 Cypriot uprising against British colonial rule is the pivot and point of departure in Alexis Rappas' well-researched and comprehensive account of Cyprus in the 1930s: British Colonial Rule and the Roots of the Cyprus Conflict. He unfolds a broad-ranging account of the colonial state, the local community and the relations between them in the 1930s. On 21 October 1931, "summoned by church bells", a procession of Cypriot political leaders, students and priests set fire to the colonial governor's residence. Their aim was to break away from British colonial rule and link up with Greece (the so-called "enosis"). This desire had gained ground especially from 1925 , in reaction to the unpopular British decision to make Cyprus a crown colony and thereby dash hopes for enosis. Protests against British rule intensified in those October days as communists strategically allied themselves with Orthodox prelates. Various groups raided government offices and police stations, ripped up the union flag and threw stones at British troops, in urban and rural Cyprus, throughout the entire island. The colonial authorities responded swiftly and restored order by the beginning of November. Nonetheless, the events sent shock waves throughout Cyprus and the British Mediterranean.

As a result of the October 1931 uprising, the colonial authorities launched a number of suppressive measures that directly affected the 
daily political and social life of the Cypriot population. For example, the legislative council, the Cypriot "parliament", was abolished and a new law forbade assemblies of more than five persons. These measures, which were extended throughout the decade, attempted to increase the colonial grip on the Cypriot public sphere, such as education, local administration and religion. By controlling these institutions and preventing the creation of intra- or pan-Cypriot solidarities, the colonial authorities aimed to mitigate Cypriot nationalist desires for enosis. In an increasingly authoritarian fashion, the colonial administration attempted to secure a certain level of autonomy from the metropolitan authorities, to isolate the island internationally and to intensify its own interactions with the local community.

As Rappas outlines, historiography tends to consider the 1931 uprising a pivotal moment between a liberal phase and an authoritarian phase of colonial rule. As a consequence the uprising radicalised the Greek Cypriot nationalist movement in its pursuit for enosis and strengthened the radical Turkish Cypriot nationalists. As such, 1931 was a watershed leading to the later division of the island and the continuing "Cyprus question". Rappas is concerned with this "dramatisation" of the 1931 rupture. He claims that 1931 did not alter the fundamental nature of the colonial regime but rather "released its full potential". Consequently, rather than departing from an outright confrontation between Cypriot nationalists and colonial authorities, his book explores "slower and less perceptible forces" in the radicalisation of local politics.

Rappas explores these "forces" in five large thematic leaps, which together provide an indepth and encompassing analysis of Cypriot society, colonial administration and statesociety relations in the 1930s. He first outlines the colonial policies enacted from beginning of the decade in the field of decentralisation, education and development. He convincingly argues that these policies were part of a more general and ambitious policy of social engineering. Especially under the influence of governor Sir Herbert Richmond Palmer (1933-1939), the colonial authorities tried to build a conflict-free society in which Cypriots would remain aloof from "politics", with a special focus on the containment of the nationalist issue. This was to be achieved through administrative decentralisation and the ensuing "neutralisation" of politics that the colonial authorities hoped for. Furthermore, the reform of elementary and secondary education would counter the affiliation of Cypriots to Greece or Turkey. And the development of agriculture would tackle peasants' dependence on moneylenders. In a later chapter, Rappas presents an anthropological analysis of the daily life of colonial civil servants. Even if colonial civil servants were supposed to estimate and anticipate the needs and political disposition of the local community, a process of estrangement characterised the relations between the colonial administration and local society. This estrangement, which ran contrary to the colonial administration's initial purpose, harmed the flow of information on the island. Rappas' subsequent and last three steps in exploring the political impact of colonial rule in Cyprus in the 1930s focus on the consequences of this imperfect implementation of social engineering. He first distinguishes Cypriot attempts to reverse the existing constitutional order, which aimed at upgrading the island's status from a colony to a dominion. One of the "vectors of politicisation" Rappas explores here convincingly is the role of cafes in the dissemination of a political consciousness. Even if the constitutionalist movement did not succeed in its principal goal, it contributed to the creation of mass politics in Cyprus. A second 
consequence is the reconstitution of a Greek Cypriot nationalist public sphere, which found fertile soil in the question of the archiepiscopal election from 1933 onwards. This question, triggered by colonial attempts to realise a clear separation of church and state, led to deepening tension between the colonial administration and the Orthodox clergy. A final consequence of the thwarted colonial attempts at social engineering is the creation of a "labour question" in Cyprus, with international dimensions, despite the colonial denial of its existence. Through these five large leaps, Rappas concludes by assessing the ideological polarisation between the nationalist right and communist left and, in the last two pages of the book, its impact on the continuing Cyprus question.

These large leaps with which Rappas strides through Cyprus in the 1930s constitute both the strength and weakness of the book. They are its strength because Rappas' account is sweeping in its embracing approach of the Cypriot local community, the colonial administration and the relations between them. The book is based on an impressive amount and variety of primary material, including surveys, statistics, correspondence and private files from the British Colonial Office, Foreign Office and War Office, the archives of the Cypriot justice and public order ministries, various published censuses, reports and articles by colonial officials, and an array of Cypriot newspapers. The archival foundation of the book is solid and far-reaching. Part of Rappas' comprehensive approach is his successful effort at embedding the case of Cyprus in two broader perspectives. First, from a geographical and thematic point of view, he makes regular comparisons with other British colonies and other colonies at large. Whereas single case studies risk national parochialism by arguing for the uniqueness of a particular case,
Cyprus in the 1930s is different. Through regular comparisons Cyprus remains part of the British colonial empire rather than enclosed within its own borders. It remains an example of a colonial state rather than the unique result of specific Cypriot circumstances: the broader thematic framework and the international context remain constantly in view. Second, from a theoretical point of view, Rappas intertwines Cyprus in the 1930s with a wide array of theoretical problems, broadening our understanding of the Cypriot case regarding, among others, the use of language by the colonial administration (Roland Barthes), the nature of colonial bureaucracies (Hannah Arendt), the authoritarian personality (Theodor Adorno), social engineering (James Scott) and the public sphere (Jürgen Habermas). These broader thematic and theoretical perspectives make Cyprus in the 1930s valuable as an in-depth analysis of the specific case of Cyprus while the book is thought-provoking in its temporal, geographical and thematic comparisons beyond the borders of this particular case.

While the book is impressive in its scope, at times it tends to lose sight of its main focus. In fact, Cyprus in the 1930s covers much more than the hypothesis articulated in the introduction. The well-researched basis of the book, its detailed and careful writing style, and its many diversions make Rappas' account convincing and strong. However, these aspects also tend to lead the reader away from the general argument and, at times, make for demanding reading. Not all sections contribute to the main argument of the book and the various chapters sometimes read as separate articles rather than part of a coherently argued monograph. Particularly in the introductory chapter the argument could have been presented in a more succinct way. In the later chapters of his book Rappas appears more at ease with his topic. 
Finally, some attention should be drawn to the teleological subtitle of the book, which promises to link the (current) Cyprus conflict to events in the 1930s. While it is tempting to extend conclusions of historical research to the present or the future, historical determinism lurks, possibly underestimating, in this case, other, later factors that may have played a (decisive) role in the creation of the current Cyprus conflict. The connection that Rappas makes in the last two pages of his book between British colonial rule in Cyprus in the 1930s and the current Cyprus conflict falls rather short and could have been more convincing.

Despite these aspects that deserved more attention, Cyprus in the 1930s should be valued for its subtle, sensitive and well-researched account of the relations between colonisers and colonised, and for its regular thought-provoking excursions to broader perspectives.

\section{Kostis Kornetis}

Children of the Dictatorship: Student Resistance, Cultural Politics and the "Long 1960s" in Greece

\author{
New York and Oxford: Berghahn \\ Books, 2013. 373 pp.
}

\section{Polymeris Voglis \\ University of Thessaly}

Every year on the anniversary of the Athens Polytechnic uprising (17 November 1973), a number of extreme rightist websites challenge what they call the "Polytechnic myth". They maintain that no civilians were killed by the police and the army during the violent suppression of the uprising, despite the fact that researchers have established that the events left 24 people dead. Even more alarming are the findings of a survey conducted in the spring of 2013 , according to which $30 \%$ of respondents believed that "things were better during the dictatorship than they are today". The economic crisis and the breakdown of the political system have led many people in Greece to sympathise with authoritarian solutions: a well-organised and disciplined society without conflict, corruption and crisis, and governed by a strongman. The appeal of authoritarianism nowadays reflects the discrediting of political developments in the decades following the fall of the dictatorship, the era known as the Metapolitefsi that has been harshly criticised as responsible for the current crisis. Moreover, the appeal of the Colonel's dictatorship (19671974) has flourished on the basis of ignorance, distortion and silence. The seven years of the dictatorship remain a largely unknown period for many Greeks. Even the majority of the people who experienced those years prefer to forget, pretending that nothing extraordinary occurred during them until the end, the Turkish 